\title{
Phytochemical screening and antioxidant activity of Clitoria guianensis
}

Daniela Francisca Soares ${ }^{1}$, Camila Luiza Cunha², Maike de Oliveira Krauser³, Juliana Cristina Holzbach 4

\section{RESUMO}

A planta Clitoria guianensis Benth é utilizada como afrodisíaco e tônico do sistema nervoso central, de acordo com estudos etnobotânicos regionais. O presente artigo visa investigar as propriedades fitoquímicas e antioxidantes desta espécie. As raízes e folhas de Clitoria guianensis foram extraídas com etanol e particionadas com diferentes solventes. As frações resultantes foram avaliadas quanto a presença das classes fitoquímicas e a atividade antioxidante foi determinada usando o método de sequestro do radical livre 2,2-difenil-1-picril-hidrazil (DPPH). As avaliações preliminares revelaram a presença de classes de metabólitos secundários como flavonoides, taninos, esteroides e saponinas. Todas as frações das folhas inibiram efetivamente o radical DPPH. A fração de acetato de etila apresentou maior atividade antioxidante $\left(\mathrm{IC}_{50} 46.3 \mu \mathrm{g} \cdot \mathrm{ml}^{-1}\right)$ esta atividade antioxidante está relacionada ao teor de flavonoides e taninos presentes na fração.

Palavras-chave: Fabaceae. Fitoquímica. Flavonoides. Taninos.

\section{ABSTRACT}

The plant Clitoria guianensis Benth is used as aphrodisiac and central nervous system tonic, according to regional ethnobotanical studies. The present study was aimed to investigate the phytochemical and antioxidant properties of this species. The roots and leaves of Clitoria guianensis were extracted with ethanol and partitioned with different solvents. The fractions results were screened for the presence of phytochemical classes and the antioxidant activity was determined using the free radical 1,1-diphenyl2-picrylhydrazyl (DPPH) sequestration method. Preliminary phytochemical screening revealed the presence of secondary metabolites classes as much as flavonoids, tannins, steroids, and saponins. All the fractions from leaves were effectively scavenge the DPPH radical. The ethyl acetate leaves fraction show greater antioxidant activity $\left(\mathrm{IC}_{50} 46.3 \mu \mathrm{g} \cdot \mathrm{ml}^{-1}\right.$ ) this antioxidant activity which is related to their flavonoids and tannins content in this fraction.

Keywords: Fabaceae. Phytochemistry. Flavonoids. Tannins.

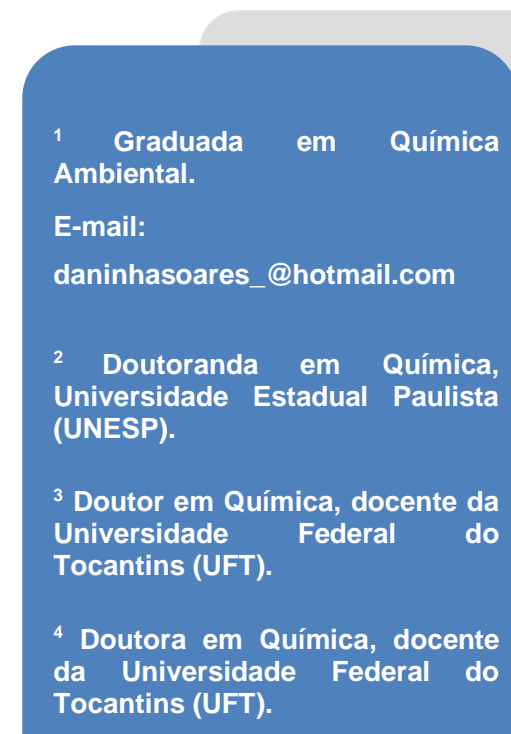

Tocantins (UFT). 


\section{INTRODUCTION}

Brazil has a notorious natural wealth, being among the 17 megadiverse countries (ARAUJO; FERNANDES; SANTOS, 2019; CABRAL; BRITO, 2013). The Cerrado is the second largest Brazilian biome, it has more than 12.000 plant species, about 4.000 of which is endemic, including almost all of the herbs and short plants (DAMASCO et al., 2018).

Brazilian biodiversity has been used for centuries by the population to treat diseases and represents an important source of bioactive compounds (BIAZOTTO et al., 2019). Approximately $67 \%$ of medicines approved products results from or are inspired by molecules obtained from natural products and, considering the classes of drugs, $73 \%$ of antibiotics and $66 \%$ of anticarcinogens come from natural substances, derived or mimicked from them (NEWMAN; CRAGG, 2016).

Several diseases are related to oxidative stress such as heart disease, atherosclerosis, Alzheimer's disease, arthritis, diabetes, cataracts and can also cause of mutagenesis and carcinogenesis. This phenomenon caused by an unbalance between production and accumulation of reactive oxygen species (ROS) in cells and tissues and the ability of a biological system to detoxify these reactive products (PIZZINO et al., 2017). Plants can be a rich source of antioxidants that result in a decrease in the amount ROS.

Species of the Clitoria genus has been traditionally used for the treatment of respiratory, neurological, urinary, and skin disorders (CHAUHAN et al., 2017; GOLLEN; MEHLA; GUPTA, 2018). This genus are in the Fabaceae family and is inserted in the Faboideae subfamily. It is represented by approximately 60 species, distributed in tropical or subtropical regions, found mainly in Brazil, the Antilles, America Central, Africa and Australia (SINGH et al., 2018; ZINGARE; ZINGARE; DUBEY, 2013).

Clitoria guianensis is found in the Cerrado, mainly in the states of Tocantins and Goiás, it is used in folk medicine in the form of decoction or "garrafadas" (medicinal plants mixed with alcoholic beverages) for mental disorders and sexual stimulant (SOUZA; FELFILI, 2006; VERDE, 2003).

Phytochemical screening for presence of secondary metabolites classes such an important medicinal plant will give prompt advantages in the discovery of novel medicine for the emerging diseases of humans. Thence of these reasons the present study was designed to explore the phytochemicals and antioxidant potencial by using different extracts of $C$. guianensis. 


\section{MATERIALS AND METHODS}

Collection, identification and preparation of plant extract: roots and leaves $C$.

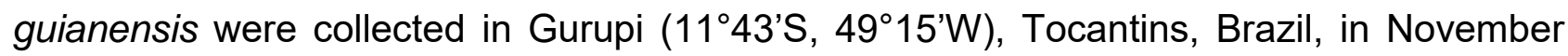
2013 and were identified in the Herbário do Tocantins (HTO), Porto Nacional, TO, Brazil (voucher specimen 10.637). After collection, the roots (398.5 g) and leaves $(200.1 \mathrm{~g})$ were separated, washed with distilled water, and completely dried. Dried samples were ground to a powder and soaked in ethanol. Solution was filtered after 7 days of soaking and fresh solvent was added. The process was repeated three times and the filtrate obtained was evaporated in a rotary evaporator. The ethanolic crude extract $(12.1 \mathrm{~g}$ and $29.8 \mathrm{~g}$, roots and leaves, respectively) were dissolved in a mixture of $\mathrm{MeOH}: \mathrm{H}_{2} \mathrm{O}(250 \mathrm{ml}, 1: 1 \mathrm{v} / \mathrm{v})$ and then subjected to liquid-liquid partition with $\mathrm{n}$-hexane $(3.3 \mathrm{~g}$ and $3.6 \mathrm{~g}$, roots and leaves, respectively) and ethyl acetate (5.4 g and $13.8 \mathrm{~g}$, roots and leaves, respectively) fractions.

Qualitative phytochemical study: The presence of phytochemicals such as flavonoids, anthocyanins, saponins, steroids, alkaloids and tannins in the plant was analyzed following standard protocols (BARBOSA, 2004; MATOS, 2009). Tannins were evaluated using a $2.5 \%$ gelatin solution with the sample. The presence of tannins was identified with appearance of a white precipitate. Saponins were detected by boiling $50 \mathrm{mg}$ the extract with $10 \mathrm{ml}$ of distilled water, this mixture was filtered and mixed with distilled water and shaken vigorously until a stable persistent froth is obtained. The formation of emulsion indicated the presence of saponins. Anthocyanins and derivatives were analyzed from the color combination of 3 tubes with different $\mathrm{pH}$ (3.0, 8.5 and 11.0); leucoanthocyanidins, catechins and flavones were determined by heating the tubes and observing if there would be a change in color. Shinoda's test was applied for flavonoids, the fractions were added some drops of concentrated hydrochloric acid and a few amounts of magnesium powder, if the color changing into red or pink indicated the sample containing flavonoid. For terpenoids to $0.5 \mathrm{~g}$ each of the fraction was added $2 \mathrm{ml}$ of chloroform, concentrated $\mathrm{H}_{2} \mathrm{SO}_{4}(3 \mathrm{ml})$ was carefully added to form a layer; a reddish brown coloration of the interface indicates the presence of terpenoids. Alkaloids were identified using a $5 \mathrm{ml}$ of $1 \%$ aqueous $\mathrm{HCl}$ on water bath and then filtered. Of the filtrate, 1 $\mathrm{ml}$ was taken individually into 2 test tubes. To the first portion, few drops of Dragendorff's reagent were added; occurrence of orange-red precipitate was taken as positive. To the 
second $1 \mathrm{ml}$, Mayer's reagent was added, and appearance of buff-colored precipitate will be an indication for the presence of alkaloids.

Antioxidant activity: The antioxidant activities of ethanolic crude extract, n-hexane and ethyl acetate fractions, from roots and leaves were determined using 1,1-diphenyl-2picrylhydrazyl radical (DPPH) free radical scavenging assay by the method of BrandWilliams. The DPPH solution was prepared in distilled methanol. Methanolic solutions of leaves samples were prepared and diluted serially to achieve concentrations of 250.0, 200.0, 150.0, 100.0, 50.0 and $20.0 \mu \mathrm{g} \cdot \mathrm{ml}^{-1}$. Methanolic solutions of ethanolic crude extract, and ethyl acetate fraction from roots were prepared and diluted serially to achieve concentrations of $500.0,350.0,200.0,150.0,100.0$ and $50.0 \mu \mathrm{g} \cdot \mathrm{ml}^{-1}$, while for the $\mathrm{n}$ hexane fraction the concentrations were 1500.0, 1200.0, 1000.0, 850.0,700.0 and 500 $\mu \mathrm{g} \cdot \mathrm{ml}^{-1} .2 .7 \mathrm{ml}$ of freshly prepared ethanolic solution of DPPH was mixed with $0.3 \mathrm{ml}$ of the sample. The mixture was incubated for $30 \mathrm{~min}$ and the absorbance measured against a blank at the end of $30 \mathrm{~min}$ at a wavelength of $517 \mathrm{~nm}$ using a Shimadzu UV/Vis 1601 apparatus (ADESANWO; MAKINDE; OBAFEMI, 2013). All experiments were performed in triplicate. Inhibition of DPPH free radical in (\%), was calculated as follows:

$$
\% \text { DPPH radical scavenging }(\%)=\left[1-\left(\frac{A s}{A c}\right)\right] \times 100
$$

Here, $A c=$ absorbance of control, As = absorbance of sample solution.

Then \% inhibitions were plotted against respective concentrations used and from the graph $\mathrm{IC}_{50}\left(\mu \mathrm{g} \cdot \mathrm{ml}^{-1}\right)$ was calculated. BHT was used as a positive control.

\section{RESULTS}

Phytochemical analyzes (table 1) involved the following samples: ethanolic crude extract (ECER) and ethyl acetate fraction (EAcFR) from roots, and ethanolic crude extract (ECEL) and ethyl acetate (EAcFL) fractions from C. guianensis leaves.

Table 1. Phytochemical screening results from roots and leaves from Clitoria guianensis.

\begin{tabular}{ccccc}
\hline \hline Phytochemical constituents & ECER & EAcFR & ECEL & EAcFL \\
\hline \hline Anthocyanins and derivatives & - & - & - & + \\
Flavones, flavonols and & +++ & ++ & - & - \\
$\quad$ xanthones & - & - & - & - \\
Chalcones and aurones & - & - & - & - \\
Flavanonol & - & - & - & -
\end{tabular}




$\begin{array}{ccccc}\text { Catechins } & - & - & - & - \\ \text { Saponins } & - & ++ & - & - \\ \text { Flavonoids } & + & + & +++ & ++ \\ \text { Tannins } & +++ & +++ & +++ & +++ \\ \text { Terpenoids } & - & - & +++ & + \\ \text { Alkaloids } & - & - & - & -\end{array}$

Key: $(+)=$ weak,$(++)=$ moderate $(+++)=$ strong presence, and $(-)=$ absent.

The DPPH test provides information on the reactivity of the samples with a stable free radical. The antioxidant activity tests (table 2) were performed with the following samples: ethanolic crude extract (ECER), n-hexane (HFR) and ethyl acetate fraction (EAcFR) from roots, and ethanolic crude extract (ECEL), n-hexane (HFL) and ethyl acetate $(\mathrm{EAcFL})$ fractions from $C$. guianensis leaves.

Table 2. Antioxidant activities $\left(\mathrm{IC}_{50}\right)$ of all samples from Clitoria guianensis.

\begin{tabular}{cc}
\hline \hline Samples & IC $_{50}\left(\mu \mathrm{g} \cdot \mathrm{ml}^{-1}\right)$ \\
\hline \hline ECER & 621.3 \\
HFR & 1286.9 \\
EAcFR & 343.6 \\
ECEL & 121.2 \\
HFL & 598.7 \\
EAcFL & 46.4 \\
\hline \hline
\end{tabular}

\section{DISCUSSION}

Plants are composed of different compounds that can be grouped into special metabolite classes. The presence of certain classes of metabolites may suggest a therapeutic potential to the sample. Phytochemical studies have been an important stage for the discovery of new therapeutic agents and the potential of medicinal plant.

Compounds belonging to a class of metabolites have basic chemical structures that give them similar physicochemical properties that can be used in qualitative tests. Table 1 showed qualitative analysis of $C$. guianensis, in roots samples (ECER and EAcFR) were presents flavones, flavonols and xanthones; tannins; and flavonoids, while saponins were restricted to EAcFR. The presence of saponins only in the EAcFR is due to their higher concentration in the fraction with the lowest polarity, compared to crude ethanolic extracts. According to IUPAC (International Union of Pure and Applied Chemistry) the term 
"flavonoids" includes several classes like flavones, isoflavones, anthocyanidins, among others. Previous studies on the roots of this plant showed the isolation of rotenoids, isoflavone, flavanones and phenolic glycosides (CUNHA et al., 2020) that corroborate with the data of the qualitative analysis.

The qualitative tests of leaves revealed the presence of flavonoids, tannins, and terpenoids, while anthocyanins and derivatives were restricted to EAcFL. Through the more accentuated staining, a higher concentration of flavonoids can be noticed in the leaves samples, which have been related to the production of flavonoids for photoprotection, among other biological functions (MIERZIAK; KOSTYN; KULMA, 2014).

Several biological systems like protein phosphorylation, activation of several transcriptional factors, apoptosis, immunity, and differentiation are dependent on a ROS production. Imbalance in the production of ROS can result in different diseases, so the search for antioxidant plants can contribute to the discovery of therapeutically active plants.

Radical DPPH, relatively stable, has been widely used in the determination of antioxidant activity of single compounds as well as the different plant extracts. DPPH method consist of to evaluate the free radical scavenging ability. The DPPH radical contains an odd electron, which was responsible for the absorbance at $517 \mathrm{~nm}$ and produces a violet solution. When DPPH accepts an electron donated by an antioxidant compound, the DPPH is decolorized, which can be quantitatively measured from the changes in absorbance.

The leaves values displayed higher DPPH scavenging activity as compared to roots samples. The $\mathrm{IC}_{50}$ values obtained ranged from 46.4 to $1286.9 \mu \mathrm{g} \cdot \mathrm{ml}^{-1}$ (table 2). EAcFL demonstrated the highest antioxidant activity $\left(46.4 \mu \mathrm{g} \cdot \mathrm{ml}^{-1}\right)$ that when compared to other plants (Heliotropium bacciferum $52.6 \mathrm{mg} / \mathrm{ml}$ (AHMAD et al., 2014); Tabernaemontana catharinensis $78.2 \mu \mathrm{g} \cdot \mathrm{ml}^{-1}$ ) (PIANA et al., 2014) may be suggest an antioxidant potential of this plant.

The ethyl acetate fractions (EAc) for roots and leaves, showed the best results of antioxidant activity. The presence of high quantity of flavonoids and derivatives in the leaves, according to phytochemical screening, justifies the variation in the $\mathrm{IC}_{50}$ values observed. Flavonoids and tannins are phenolic compounds that have chemical structures with a high capacity to act as primary antioxidants or free radical scavengers (MIERZIAK; KOSTYN; KULMA, 2014). 


\section{CONCLUSION}

C. guianensis is the source of the secondary metabolites ranging from flavones, flavonols and xanthones; tannins; flavonoids, anthocyanins and derivatives; saponins and terpenoids compounds. These compounds, especially the phenolics, contributed to the antioxidant capacity of the plant. The phytochemical screening and antioxidant capacity of the plant plays an important role for future quantitative analysis and pharmaceutical studies.

\section{REFERENCES}

ADESANWO, J. K.; MAKINDE, O. O.; OBAFEMI, C. A. Phytochemical analysis and antioxidant activity of methanol extract and betulinic acid isolated from the roots of Tetracera potatoria. Journal of Pharmacy Research, v. 6, n. 9, p. 903-907, 2013. Disponível em: <http://www.sciencedirect.com/science/article/pii/S0974694313003629>.

AHMAD, S. et al. Phytochemical Analysis, Antioxidant Activity, Fatty Acids Composition, and Functional Group Analysis of Heliotropium bacciferum. The Scientific World Journal, v. 2014, p. 829076, 2014. Disponível em: <https://doi.org/10.1155/2014/829076>.

ARAUJO, W. S. D.; FERNANDES, G. W.; SANTOS, J. C. An overview of inventories of gall-inducing insects in Brazil: looking for patterns and identifying knowledge gaps. Anais da Academia Brasileira de Ciências, v. 91, 2019. Disponível em:

<http://www.scielo.br/scielo.php?script=sci_arttext\&pid=S0001$37652019000100617 \& \mathrm{nrm}=$ iso $>$.

BARBOSA, W. L. R. Manual para Análise Fitoquímica e Cromatográfica de Extratos Vegetais. Revista Científica da UFPA, v. 4, 2004.

BIAZOTTO, K. R. et al. Brazilian Biodiversity Fruits: Discovering Bioactive Compounds from Underexplored Sources. Journal of Agricultural and Food Chemistry, v. 67, n. 7, p. 1860-1876, 2019. Disponível em: <https://doi.org/10.1021/acs.jafc.8b05815>.

CABRAL, R.; BRITO, D. Temporal and spatial investments in the protected area network of a megadiverse country. Zoologia (Curitiba), v. 30, p. 177-181, 2013. Disponível em: $<$ http://www.scielo.br/scielo.php?script=sci_arttext\&pid=S198446702013000200007\&nrm=iso>.

CHAUHAN, N. et al. A Review on Clitoria ternatea(Linn.): Chemistry and Pharmacology. In: KSHETRIMAYUM, B. Medicinal Plants and its Therapeutic Uses. Foster City: OMICS Group eBooks, 2017.

CUNHA, C. L. et al. A New Isoflavone and Other Constituents from Roots of Clitoria guianensis. Journal of the Brazilian Chemical Society, v. 31, n. 8, p. 1753-1757, 2020.

DAMASCO, G. et al. The Cerrado Biome: a forgotten biodiversity hotspot. Frontiers for 
Young Minds, v. 6, p. 1-10, 2018.

GOLLEN, B.; MEHLA, J.; GUPTA, P. Clitoria ternatea Linn: A Herb with Potential Pharmacological Activities: Future Prospects as Therapeutic Herbal Medicine. Journal of Pharmacological Reports, v. 3, n. 1, p. 141-149, 2018.

MATOS, F. J. A. Introdução à fitoquímica experimental. Fortaleza: Edicões UFC, 2009.

MIERZIAK, J.; KOSTYN, K.; KULMA, A. Flavonoids as Important Molecules of Plant Interactions with the Environment. Molecules. v. 19, n. 10, 2014

NEWMAN, D. J.; CRAGG, G. M. Natural Products as Sources of New Drugs from 1981 to 2014. Journal of Natural Products, v. 79, n. 3, p. 629-661, 25 mar. 2016. Disponível em: $<$ https://doi.org/10.1021/acs.jnatprod.5b01055>.

PIANA, M. et al. Phytochemical analysis and antioxidant capacity of Tabernaemontana catharinensis A. DC. Fruits and branches. Anais da Academia Brasileira de Ciências, v. 86, p. 881-888, 2014. Disponível em:

$<$ http://www.scielo.br/scielo.php?script=sci_arttext\&pid=S0001$37652014000200881 \& \mathrm{nrm}=\mathrm{iso}$.

PIZZINO, G. et al. Oxidative Stress: Harms and Benefits for Human Health. Oxidative medicine and cellular longevity, v. 2017, p. 8416763, 2017. Disponível em: $<$ https://pubmed.ncbi.nlm.nih.gov/28819546>.

SINGH, N. K. et al. Anti-allergy and anti-tussive activity of Clitoria ternatea Linn experimental animals. Journal of Ethnopharmacology, v. 224, p. 15-26, 2018. Disponível em: <http://www.sciencedirect.com/science/article/pii/S0378874117340771>.

SOUZA, C. D. DE; FELFILI, J. M. Uso de plantas medicinais na região de Alto Paraíso de Goiás, GO, Brasil. Acta Botanica Brasilica, v. 20, p. 135-142, 2006. Disponível em: $<$ http://www.scielo.br/scielo.php?script=sci_arttext\&pid=S010233062006000100013\&nrm=iso>.

VERDE, V. Levantamento etnobotânico das plantas medicinais do cerrado utilizadas pela população de Mossâmedes ( GO ). Revista Brasileira de Farmacognosia, v. 13, p. 6466, 2003.

ZINGARE, M. L.; ZINGARE, P. L.; DUBEY, A. K. Clitoria ternatea (APARAJITA): a review of the antioxidant, antidiabetic and hepotoprotective potentials. International Journal of Pharmacy and Biological Sciences, v. 3, n. 1, p. 203, 2013. 